ISSN 1027-5495. Functional Materials, 24, No.3 (2017), p. 451-456

doi:https://doi.org/10.15407/fm24.03.451

(C) 2017 - STC “Institute for Single Crystals"

\title{
Nonlinear analysis of concrete-filled steel square tube strengthened by internal transverse stiffened bars under axial compression
}

\author{
Nan $\mathrm{Li}^{12}$, Lai Wang ${ }^{2}$, Yajun $X i^{3}$, Tong Guan', \\ Hui Wang ${ }^{1}$, Furui Dong ${ }^{1}$ \\ ${ }^{1}$ Department of Resources and Civil Engineering, Shandong University of \\ Science \& Technology, Taian, 271000, China \\ ${ }^{2}$ School of Civil Engineering and Architecture,Shandong University of \\ Science and Technology, Qingdao, 266590,China \\ ${ }^{3}$ Tai'an engineering construction standard cost office, Taian, Shandong, \\ 271000,China;
}

Received 25 February, 2017

\begin{abstract}
A new type of concrete-filled square steel tubular(CFSST) column is proposed, which is characterized by the transverse stiffened steel bars arranged inside the pipe wall to improve confinement performance of the concrete core. This paper employs a nonlinear analysis of square CFSST stub columns under axial compression. A three-dimensional nonlinear finite element (FE) model is developed using ABAQUS, where nonlinear material behavior and enhanced strength corner properties of steel are included. Close agreement is achieved between the test and FE results in terms of load-deformation response and ultimate strength.

Keywords: Internal transverse stiffened bars, concrete-filled steel square tube, axial compression, finite element, strength

Для улучшения характеристик удержания бетонного сердечника предлагается новый тип колонны из бетона с квадратной стальной трубой (CFSST), который характеризуется поперечными упрочняющими стальными стержнями, расположенными внутри стенки трубы, В настоящей работе используется нелинейный анализ квадратных столбиков CFSST при осевом сжатии. Трехмерная нелинейная модель конечного элемента (FE) разработана с использованием ABAQUS, в которую включены нелинейное поведение материала и усиленные угловые свойства стали. Достигнуто близкое согласие между результатами испытаний и FE в терминах нагрузки и деформации.
\end{abstract}

Нелінійний аналіз залізобетонної сталевий квадратної труби, посилений внутрішніми поперечними зміцненими стрижнями під осьовим стисненням. Nan Li, Lai Wang, Yajun Xi, Tong Guan, Hui Wang, Furui Dong.

Для поліпшення характеристик утримання бетонного сердечника пропонуеться новий тип колони з бетону з квадратної сталевою трубою (CFSST), який характеризуеться поперечними упрочняющими сталевими стрижнями, розташованими всередині стінки труби. У даній роботі використовуеться нелінійний аналіз квадратних стовпчиків CFSST при осьовому стисненні. Тривимірна нелінійна модель кінцевого елемента (FE) розроблена з використанням ABAQUS, в яку включені нелінійне поведінку матеріалу і посилені кутові властивості стали. Досягнуто близьке згоду між результатами випробувань i FE в термінах навантаження і деформації. 


\section{Introduction}

The concrete-filled steel square tubular concrete structure is composed of two different properties of steel and concrete. It provide not only an increase in the load carrying capacity but also rapid construction, and additional cost saving [1, 2]. Based on the above characteristics, the theoretical research and engineering application of concretefilled steel tubular composite structure in civil engineering has become more and more extensive in recent years [3-6].

Furlong [7] studied the axial and bending ultimate bearing capacity of 22 square-shaped CFST columns through the axial and bending tests. Knowles et al. [8] studied the ultimate bearing capacity of concrete-filled square steel tubes. The influence of slenderness and other factors on the axial compression performance is analyzed and compared with the section of the hollow steel pipe. Shkir K [9] studied the axial performance of 11 CFSST columns with length of $3 \mathrm{~m} \sim 5 \mathrm{~m}$, and compared with the numerical results of finite element numerical simulation. Brian Uy[10]proposed a nonlinear fiber analysis method for the three-dimensional nonlinear analysis of concrete-filled steel tubular columns, which is used to predict the ultimate strength and behavior of short concrete filled steel box columns with local buckling effect. the ratio of $\mathrm{L} / \mathrm{b}$, aspect ratio $\mathrm{b} / \mathrm{t}$ and other factors to the circumferential strain of the column were analyzed. M. Dundu[11] carried out the axial compression test of 29 square steel tube concrete specimens. The formula for calculating the bearing capacity of short columns and middle columns is put forward. X.H.Dai[12] studied the axial compression performance of concretefilled square steel tubular column after fire and put forward the formula of bearing capacity concrete-filled square steel tube under high temperature circumstance.

Finite element (FE) analyses are frequently being used as a tool by researchers to investigate the behavior of structural members $[13,14]$. FE models show accurate results when compared with experimental works for differ- ent case studies. This paper aims to perform a nonlinear analysis of square CFSST stub columns under axial compression. Previous available test results are used in the present study to establish consistent FE modeling technique using ABAQUS [15,16], where nonlinear material behavior, enhanced strength corner properties of steel, and initial geometric imperfections are included. Using the FE model, the behavior of CFSST columns is compared with that of carbon steel composite columns. A series of parametric studies is further carried out to investigate the effects of different parameters on the behavior of CFSST columns.

\section{Finite element model and verification}

\section{1 configuration of specimen}

All specimens were fabricated by steel sheeting with thickness of $4 \mathrm{~mm}$. The dimension of the section is $200 \times 200 \mathrm{~mm}$, the height is $600 \mathrm{~mm}$. The spacing of internal transverse stiffened bars is $50 \mathrm{~mm}, 75 \mathrm{~mm}$ and $100 \mathrm{~mm}$ individually, the diameter of stiffened bars is $4 \mathrm{~mm}$ and $6 \mathrm{~mm}$, the length of stiffened bars is $180 \mathrm{~mm}$. The material of the steel plate is $\mathrm{Q} 235 \mathrm{~B}$, the stiffened bar is HPB335. The dimension of specimen is shown in Table 1.

\subsection{Unit selection and meshing}

\subsubsection{Unit selection}

Unit selection is necessary in the structural nonlinear analysis mainly for square steel, horizontal steel and concrete. In concrete-filled steel square tube strengthened by internal transverse stiffened bars, The steel tube was simulated by using 4-node shell elements with reduced integration (S4R). The concrete core was modeled using 8 -node brick elements (C3D8R), with three translation degrees of freedom at each node. The beam unit selects unit B33 for simulation. Considering the actual size of the column model, the height is $600 \mathrm{~mm}$, the cross section is $200 \mathrm{~mm}$ width, so the grid size is $25 \mathrm{~mm}$ by grid analysis and calculation.

Table 1. List of specimens

\begin{tabular}{|c|c|c|c|c|c|c|}
\hline specimen & width, mm & height, mm & $\mathrm{t}, \mathrm{mm}$ & $\begin{array}{c}\text { Diameter, } \\
\mathrm{mm}\end{array}$ & length, mm & spacing, mm \\
\hline A0 & 200 & 600 & 4 & None & None & None \\
\hline A1 & 200 & 600 & 4 & 4 & 180 & 100 \\
\hline A2 & 200 & 600 & 4 & 4 & 180 & 75 \\
\hline A3 & 200 & 600 & 4 & 4 & 180 & 50 \\
\hline A4 & 200 & 600 & 4 & 6 & 180 & 100 \\
\hline A5 & 200 & 600 & 4 & 6 & 180 & 75 \\
\hline A6 & 200 & 600 & 4 & 6 & 180 & 50 \\
\hline
\end{tabular}




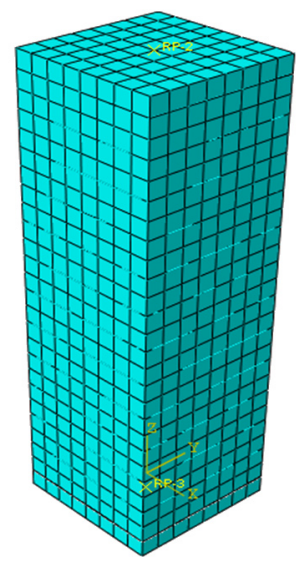

Fig. (1). Model and meshing

2.2.2 Interaction between steel pipes, concrete and transverse stiffened bars

As concrete-filled steel square tube strengthened by internal transverse stiffened bars is composed of steel pipe, transverse stiffened bars and concrete, it is necessary to consider the relationship between the two contact between each other, that is, the column square pipe and the concrete core, the welding connection between the rebar and the inner wall of the square steel tube and the transverse reinforcement and the concrete core. As the concrete stiffness is larger than steel, so the choice of concrete as the main surface, steel pipe for the subordinate, steel and concrete contact surface selection of surface contact properties (Surface to Surface Contact) to simulate, along the contact surface is taken as a hard contact (hard contact), can better simulate the interface between steel and concrete interface performance. The Coulomb friction model is used to simulate the tangential force of the contact interface in this paper, a friction coefficient of 0.25 was used in those models. The embedded element command is used to simulate the interaction between the transverse reinforcement and the concrete in the concrete-filled square steel tubular column. Use the embed command to embed the various transverse bars in the concrete. In the assembly step, the horizontal bars are merged at different intervals (Merge) to form an entity, after which the reinforcement is tiled with the inner wall of the pipe. Part of model and meshing as shown in Fig. 1

\subsubsection{Material modeling}

(1) Constitutive model of steel

The steel used in the test is low carbon steel Q235B.In order to simplify the calculation, in the finite element software of ABAQUS, the stress-strain relation of steel strip is considered in the analysis. The steel yield strength and tensile strength are selected measured values



Fig. 2. Constitutive model of steel.



Fig. 3. Constitutive model of concrete.

by computer simulation. The constitutive relation of steel is based on the double broken line model, as shown in Fig. 2.

(2) Constitutive model of concrete

Considering the special structure form of concrete filled square steel tube strengthened by internal bars, the strength and ductility of concrete core in tube were improved to a certain extent due to restriction of steel tube and transverse reinforcement, in the ABAQUS finite element model. Han[17]proposed the concrete constitutive model. The constitutive relation curves are shown in Fig. 3.

\section{Finite element simulation results analysis}

\subsection{Comparison of finite element simu-} lation and experimental bearing capacity

The finite element analysis results and experimental results are presented in Table 2, which is based on the ABAQUS finite element software.

The simulation results of load-displacement curves and load displacement curves obtained from finite element analysis are compared with those obtained by ABAQUS finite element software. The results are shown in Fig. 4. 

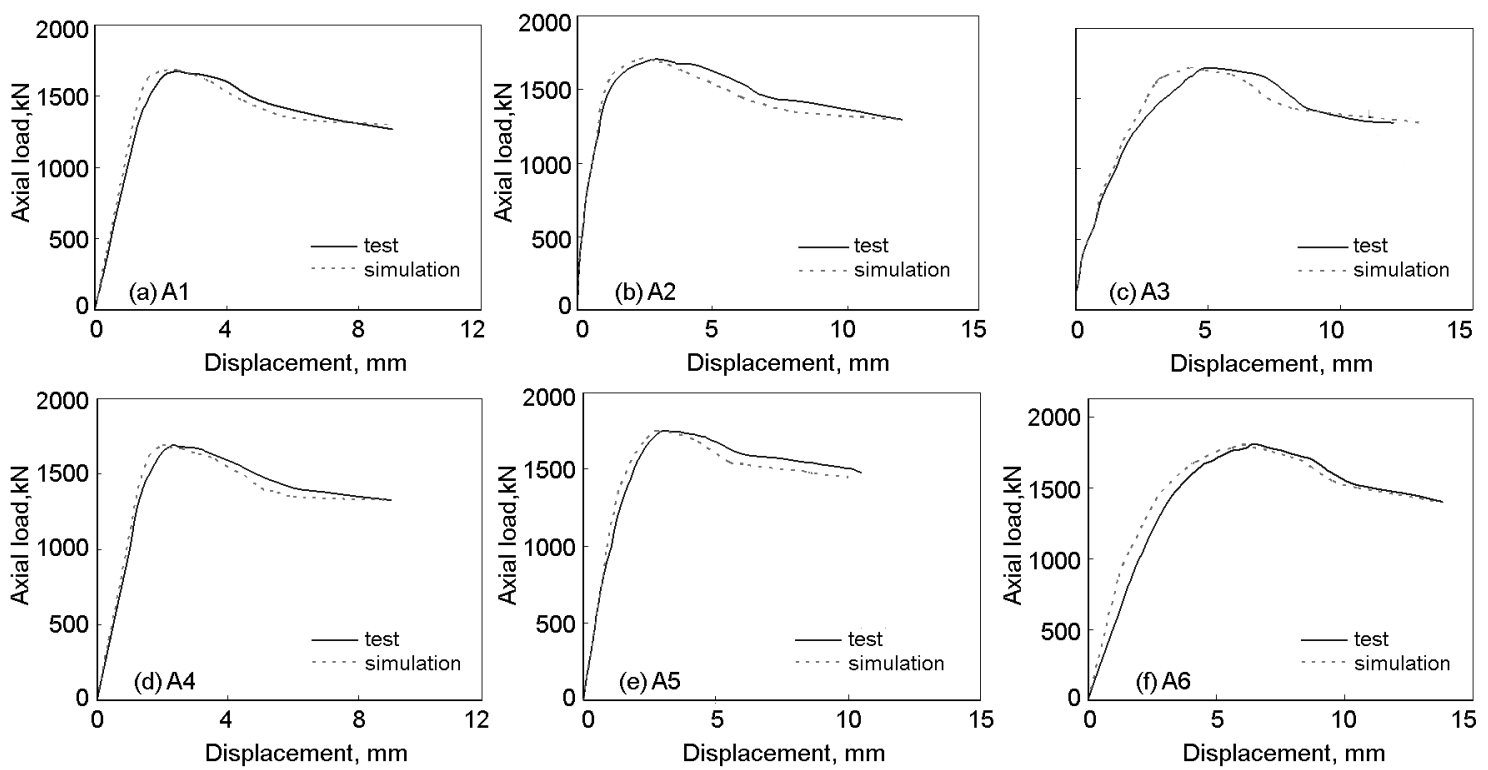

Fig. 4. Comparison of finite element result and test.

Table 2 Comparison of finite element result and test

\begin{tabular}{|c|c|c|c|}
\hline $\begin{array}{c}\text { Speci- } \\
\text { men }\end{array}$ & $\begin{array}{c}\text { Load } \\
\text { capability by } \\
\text { simulation, kN }\end{array}$ & $\begin{array}{c}\text { Load } \\
\text { capability } \\
\text { by test, kN }\end{array}$ & $\begin{array}{c}\text { Different } \\
(\%)\end{array}$ \\
\hline A0 & 1570 & 1630 & 3.82 \\
\hline A1 & 1607 & 1650 & 2.68 \\
\hline A2 & 1670 & 1700 & 1.80 \\
\hline A3 & 1720 & 1750 & 1.74 \\
\hline A4 & 1640 & 1690 & 3.05 \\
\hline A5 & 1710 & 1800 & 5.26 \\
\hline A6 & 1806 & 1860 & 2.99 \\
\hline
\end{tabular}

It can be seen from Fig. 4 that specimens of finite element analysis software of the loaddisplacement curve reflects the characteristics of linear increase, nonlinear increase, decline after peaking, it is in good agreement with the experimental curves. Compared with test results, the numerical simulation of the bearing capacity is a little bigger, it is owing to the ideal load condition and material properties.

\subsection{Specimen stress analysis}

The stress analysis of reinforced concrete column with internal transverse stiffener is shown in Fig. 5.

As seen from Fig. 5, because of the built-in transverse reinforced set of square steel tube coagulation corner stress decreases, with the increase of transverse reinforcement spacing, reinforcement constraint effect on the core con-

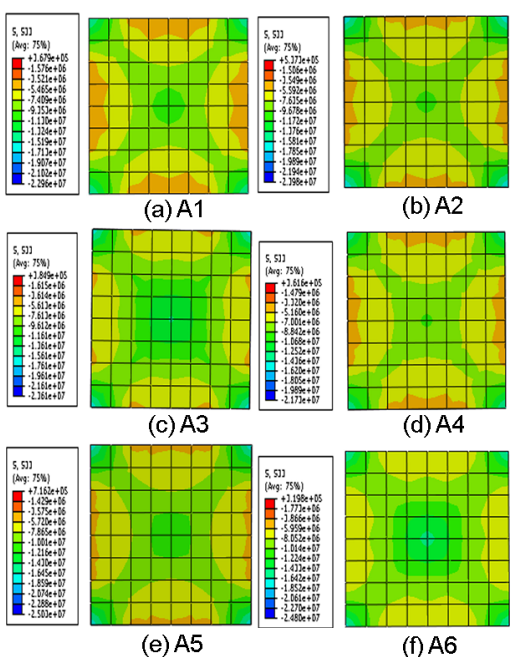

Fig. 5. Longitudinal stress distribution of section

crete, around the weak constraint area narrow, center area increases, improve the compressive strength of core concrete, section stress is uniform the specimen axial bearing capacity increase, that built in the transverse stiffener structure on the axial compressive bearing capacity is more effective.

\subsection{Parametric analysis}

\subsubsection{Effect of square steel tube strength}

The effect of steel with different yield strength on the mechanical properties of reinforced concrete filled square steel tubular column. The thickness of the steel plate is $4 \mathrm{~mm}$, and the yield strength is $235 \mathrm{~N} / \mathrm{mm}^{2}, 345 \mathrm{~N} / \mathrm{mm}^{2}, 420 \mathrm{~N} / \mathrm{mm}^{2}$. Steel HPB335 steel, concrete strength grade C30. The results of numerical simulation on the bearing capacity of concrete-filled square 

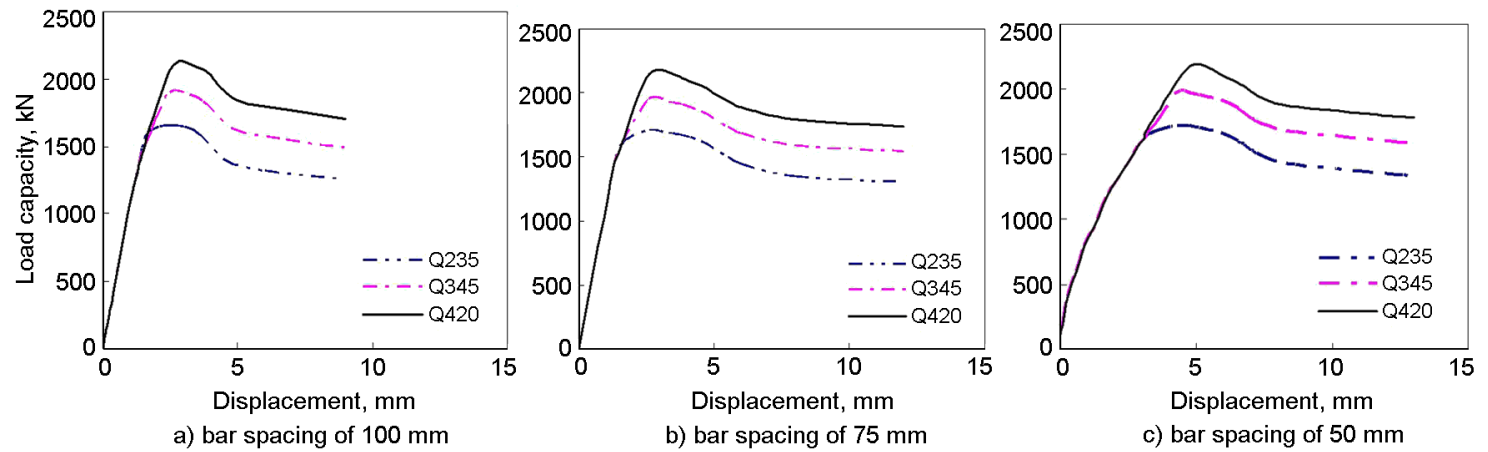

Fig. 6. Load-displacement curve with different bar spacing.

Table 3 Comparsion of load capacity on column with different steel strength

\begin{tabular}{|c|c|c|c|c||}
\hline $\begin{array}{c}\text { Speci- } \\
\text { mens }\end{array}$ & $\begin{array}{c}\text { Bar ar- } \\
\text { rangement }\end{array}$ & $\begin{array}{c}\mathrm{Q} 235 \\
(\mathrm{kN})\end{array}$ & $\begin{array}{c}\mathrm{Q} 345 \\
(\mathrm{kN})\end{array}$ & $\begin{array}{c}\mathrm{Q} 420 \\
(\mathrm{kN})\end{array}$ \\
\hline 1 & $\varnothing 450 \mathrm{~mm}$ & 1720 & 1980 & 2270 \\
\hline 2 & $\varnothing 4 \times 75 \mathrm{~mm}$ & 1690 & 1930 & 2260 \\
\hline 3 & $\varnothing 4 \times 100 \mathrm{~mm}$ & 1640 & 1900 & 2210 \\
\hline
\end{tabular}

steel tubular columns with lateral stiffeners are shown in Table 3 . The comparison curves of load displacement and bearing strength under different steel strength are shown in Fig. 6 and Fig. 7.

As seen from Fig. 6, it is shown that with the enhancement of the strength of steel, the peak load displacement curve of up to a certain extent, the rise in the range of about $15 \%$, therefore, increase the yield strength of steel can improve the bearing capacity of reinforced concrete with horizontal square steel tube column.

As seen from Fig. 7. it is shown that when steel yield strength increases, the bearing capacity of concrete reinforced with horizontal square steel tubular column with steel yield strength increase linearly and growth trend has little effect on the linear growth of bar spacing.
Table 4. The steel plate thickness of conversion with different space

\begin{tabular}{|c|c|c|c|}
\hline $\begin{array}{c}\text { Type of bar } \\
\text { arrangement }\end{array}$ & $\mathrm{S}=50 \mathrm{~mm}$ & $\mathrm{~S}=75 \mathrm{~mm}$ & $\mathrm{~S}=100 \mathrm{~mm}$ \\
\hline $4 \mathrm{~mm}-\varnothing 4$ & 4.27 & 4.21 & 4.14 \\
\hline $4 \mathrm{~mm}-\varnothing 6$ & 4.6 & 4.47 & 4.3 \\
\hline
\end{tabular}

\subsubsection{Amount of steel}

Under the condition of the same amount of steel pipe concrete filled square steel tubular column and the horizontal reinforced concrete filled square steel tubular column, the bearing capacity of the two kinds of structural columns is calculated and analyzed. In the case of the same amount of steel, according to the formula (1) to calculate.

$$
t^{\prime}=n \frac{\pi d^{2}}{4} l / b h
$$

where: $n$ - the number of transverse reinforcement; $d$-cross sectional area of bar; $l$ - length of internal transverse stiffened bar; $b, h$ - width and height of concrete filled square steel tubular specimen.

After calculation, the thickness of the steel plate with different spacing is shown in table 4 .

The results of numerical simulation of concrete filled square steel tubular column with inner transverse stiffening steel bars and

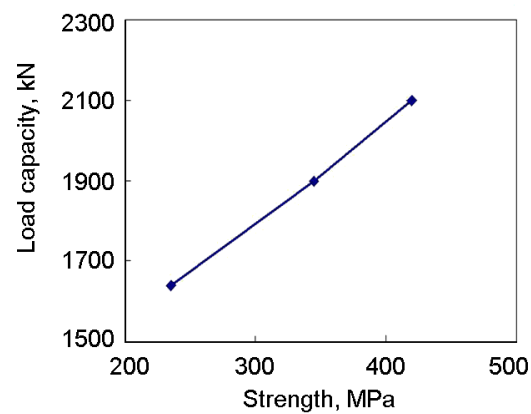

a) bar spacing of $100 \mathrm{~mm}$

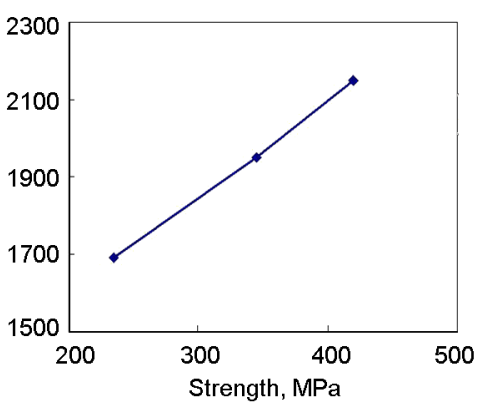

b) bar spacing of $75 \mathrm{~mm}$

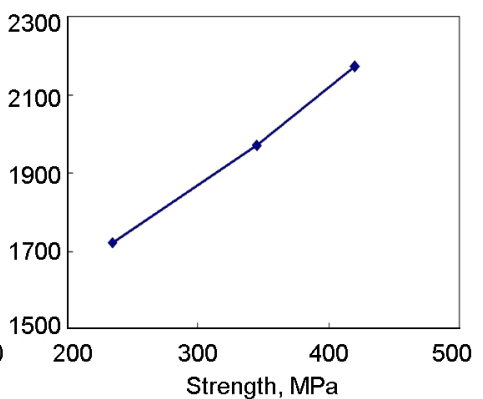

c) bar spacing of $50 \mathrm{~mm}$

Fig. 7. Load capacity-strength curve with different steel strength. 
Table 5 Comparison of bearing capacity between different columns

\begin{tabular}{|c|c|c|c|}
\hline $\begin{array}{c}\text { Specimen } \\
\text { lable }\end{array}$ & $\begin{array}{c}\text { Load } \\
\text { capacity, } \\
\mathrm{kN}\end{array}$ & $\begin{array}{c}\text { Conver- } \\
\text { sion } \\
\text { thickness }\end{array}$ & $\begin{array}{c}\text { Load ca- } \\
\text { pacity, kN }\end{array}$ \\
\hline 4 -C $30 \varnothing 4 \times 50$ & 2060 & $4.27-\mathrm{C} 30$ & 1957 \\
\hline $4-\mathrm{C} 30 \varnothing 4 \times 75$ & 2010 & $4.21-\mathrm{C} 30$ & 1939 \\
\hline $4-\mathrm{C} 30 \varnothing 4 \times 100$ & 1940 & $4.14-\mathrm{C} 30$ & 1920 \\
\hline
\end{tabular}

concrete columns with different thickness are shown in Table 5.

Comparison of the bearing capacity of concrete filled square steel tube column strengthened with transverse reinforced concrete columns under the same amount of steel is shown in Fig. 8.

Through the analysis of Fig. 8 and Table 5, in the same amount of steel under the condition with the bearing capacity of concrete filled steel tube column is higher than that of transverse reinforcement bearing capacity of concrete filled square steel tube column, transverse reinforcement spacing is dense, improve the effect of better, the simulation results show that the increase in the range of about $5 \%$.

\section{Conclusion}

Nonlinear analysis of concrete-filled steel square tube strengthened by internal transverse stiffened bars under axial compression is carried out by using ABAQUS finite element software, the numerical simulation results and experimental results were compared and analyzed, conclusions about influence on bearing capacity are drawn as follow.

(1)ABAQUS finite element software can be used for the simulation analysis of the axial compressive bearing capacity of concrete filled square steel tubular column with internal transverse stiffened bars. Compared with the test results, the simulation results agree well.

(2)with the increase of yield strength, the bearing capacity of reinforced concrete filled square steel tubular column with lateral reinforcement is increased, but the increase is small.

(3)with the increase of the yield strength of steel pipe, the bearing capacity of concrete filled square steel tubular column strengthened with transverse stiffening steel is increased, and the growth rate is linear.

(4)under the same amount of steel, the bearing capacity of the concrete-filled square steel tubular column is better than that of the concrete filled square steel tubular column.

\section{Acknowledge}

The authors gratefully acknowledge the fi $\neg$ nancial support from the Technology Project

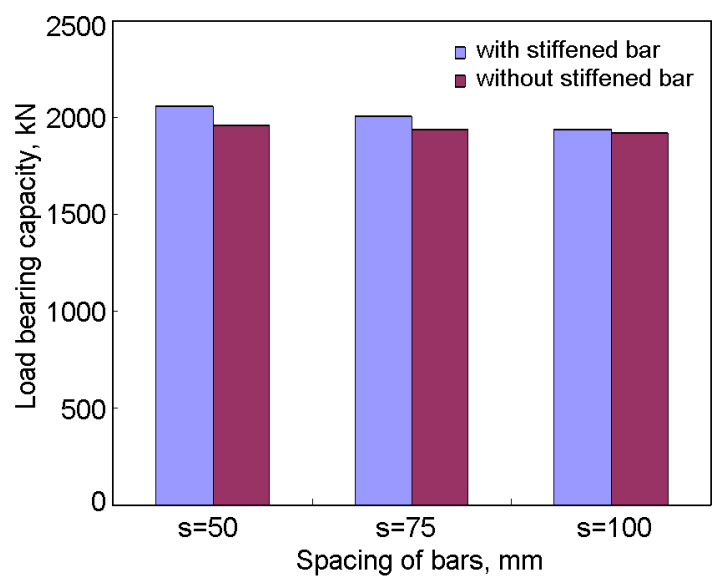

Fig. 8. Comparison of bearing capacity between CFST column and CFST column with internal stiffened transverse bars under the same steel consumption

of Shandong Province Construction Department of Urban and Rural Housing of China under Grant No. 2016KY028 and Scientific Research Innovation Team Support Plan of Department of Resources and Civil Engineering of Shandong University of Science and Technology.

\section{References}

1. B. Uy, S.B. Patil, Struct Des Tall Build, 5(2),75, 2006.

2. Zhao XL, Han LH, Lu H., Concrete-filled tubular members and connections. London, Spon Press, 2010.

3. Zhong Shan Tong. Steel Pipe Concrete (3rd Edition). Beijing: Tsinghua University Press, 2002.

4. Han Linhai, Concrete-filled steel tube structure theory and practice,Beijing, Science Press, 2004

5. Han Linhai, Yang Youfu. Modern concrete-filled steel tube technology, China Construction Industry Press, 2004

6. Zhong Shan Tong. High-rise concrete-filled steel tube structure, Harbin: Heilongjiang Science and Technology Press, 1997

7. R. W. Furlong, J. Struct. Div.,93(5),113, 1967.

8. R. B . Knowles, R. Park. J. Struct. Div. ASCE. , 95(2), 2565, 1969

9. H. Shakir-Khalil, J. Zeghiche, Struct. Engin., 67(9), 346, 1989.

10. Brian Uy, J.Y. Richard Liew. J.Constr.Steel Res., 62(6), 58111, 2006.

11. M. Dundu, Eng. Struct.,127,73, 2016

12. X.H. Dai, D. Lam, J. Constr. Steel Res., 73, 117, 2012,

13. Han LH, Yao GH, Tao Z. . Thin-Walled Structures, 45 (1), 24, 2007.

14. Tao Z, Uy B, Han LH, Wang ZB. Thin-Walled Structures, 47(12), 1544, 2009.

15. Hibbitt, Karlsson\&Sorensen, INC, Getting Started with ABAQUS, 2005.

16. ABAQUS. ABAQUS standard user's manual, version 6.9. Providence, RI (USA), Dassault Systymes Corp, 2009.

17. Han Lin-hai,Feng Jiu-bin, J. Harbin Univ. Arch., 28(5),26, 1995 